\title{
Editorial
}

\section{RESILIENT PEOPLE RESILIENT PLANET: A Future Worth Choosing}

In 2030, a child born in 2012 - the year our report is published - will turn 18. Will we have done enough in the intervening years to give her the sustainable, fair and resilient future that all of our children deserve? This report is an effort to give her an answer.

1. Today our planet and our world are experiencing the best of times, and the worst of times. The world is experiencing unprecedented prosperity, while the planet is under unprecedented stress.

2. Every day, millions of choices are made by individuals, businesses and governments. Our common future lies in all those choices. Because of the array of overlapping challenges the world faces, it is more urgent than ever that we take action to embrace the principles of the sustainable development agenda. It is time that genuine global action is taken to enable people, markets and governments to make sustainable choices.

3. The need to integrate the economic, social and environmental dimensions of development so as to achieve sustainability was clearly defined a quarter of a century ago. It is time to make it happen.

4. The challenges we face are great, but so too are the new possibilities that appear when we look at old problems with new and fresh eyes. These possibilities include technologies capable of pulling us back from the planetary brink; new markets, new growth and new jobs emanating from game-changing products and services; and new approaches to public and private finance that can truly lift people out of the poverty trap.

5. The long-term vision of the High-level Panel on Global Sustainability is to eradicate poverty, reduce inequality and make growth inclusive, and production and consumption more sustainable, while combating climate change and respecting a range of other planetary boundaries. This reaffirms the landmark 1987 report by the World Commission on Environment and Development, "Our Common Future" (United Nations document A/42/427, annex), known to all as the Brundtland report.

6. But what, then, is to be done if we are to make a real difference for the world's people and the planet? We must grasp the dimensions of the challenge. We must recognize that the drivers of that challenge include unsustainable lifestyles, production and consumption patterns and the impact of population growth. As the global population grows from 7 billion to almost 9 billion by 2040, and the number of middle-class consumers increases by 3 billion over the next 20 years, the demand for resources will rise exponentially. By 2030, the world will need at least 50 per cent more food, 45 per cent more energy and 30 per cent more water - all at a time when environmental boundaries are throwing up new limits to supply. This is true not least for climate change, which affects all aspects of human and planetary health.

7. The current global development model is unsustainable. We can no longer assume that our collective actions will not trigger tipping points as environmental thresholds are breached, risking irreversible damage to both ecosystems and human communities.

8. A quarter of a century ago, the Brundtland report introduced the concept of sustainable development to the international community as a new paradigm for economic growth, social equality and environmental sustainability. The report argued that sustainable development could be achieved by an integrated policy framework embracing all three of those pillars. The Brundtland report was right then, and it remains right today. The problem is that, 25 years later, sustainable development remains a generally agreed concept, rather than a dayto-day, on-the-ground, practical reality. The Panel has asked itself why this is the case, and what can now be done to change that.

9. The Panel has concluded that there are two possible answers. They are both correct, and they are interrelated. Sustainable development has undoubtedly suffered from a failure of political will. It is difficult to argue against the principle of sustainable development, but there are few incentives to put it into practice when our policies, politics and institutions disproportionately reward the short term. In other words, the policy dividend is long-term, often intergenerational, but the political challenge is often immediate.

10. There is another answer to this question of why sustainable development has not been put into practice. It is an answer that we argue with real passion: the concept of sustainable development has not yet been incorporated into the mainstream national and international economic policy debate. Most economic decision makers still regard sustainable development as extraneous to their core responsibilities for macroeconomic management and other branches of economic policy. Yet integrating environmental and social issues into economic decisions is vital to success.

11. For too long, economists, social activists and environmental scientists have simply talked past each other — almost speaking different languages, or at least different dialects. The time has come to unify the disciplines, to develop a common language for sustainable development that transcends the warring camps; in other words, to bring the sustainable development paradigm into mainstream economics. That way, politicians and policymakers will find it much harder to ignore.

12. That is why the Panel argues that the international community needs what some have called "a new political economy" for sustainable development. This means, for example: radically improving the interface between environmental science and policy; recognizing that in certain environmental domains, such as climate change, there is "market failure", which requires both regulation and what the economists would recognize as the pricing of "environmental externalities", while making explicit the economic, social and environmental costs of action and inaction; recognizing the importance of innovation, new technologies, international cooperation and investments responding to these problems and generating further prosperity; recognizing that an approach should be agreed to quantify the economic cost of sustained social exclusion - for example, the cost of excluding women from the workforce; recognizing that private markets alone may be incapable of generating at the scale necessary to bring about a proper response to the food security crisis; and requiring international agencies, national Governments and private corporations to report on their annual sustainable development performance against agreed 
sustainability measures. We must also recognize that this is a core challenge for politics itself. Unless the political process is equally capable of embracing the sustainable development paradigm, there can be no progress.

13. The scale of investment, innovation, technological development and employment creation required for sustainable development and poverty eradication is beyond the range of the public sector. The Panel therefore argues for using the power of the economy to forge inclusive and sustainable growth and create value beyond narrow concepts of wealth. Markets and entrepreneurship will be a prime driver of decision-making and economic change. And the Panel lays down a challenge for our Governments and international institutions: to work better together in solving common problems and advancing shared interests. Quantum change is possible when willing actors join hands in forward-looking coalitions and take the lead in contributing to sustainable development.

14. The Panel argues that by embracing a new approach to the political economy of sustainable development, we will bring the sustainable development paradigm from the margins to the mainstream of the global economic debate. Thus, both the cost of action and the cost of inaction will become transparent. Only then will the political process be able to summon both the arguments and the political will necessary to act for a sustainable future.

15. The Panel calls for this new approach to the political economy of sustainable development so as to address the sustainable development challenge in a fresh and operational way. That sustainable development is right is self-evident. Our challenge is to demonstrate that it is also rational - and that the cost of inaction far outweighs the cost of action.

16. The Panel's report makes a range of concrete recommendations to take forward our vision for a sustainable planet, a just society and a growing economy:

a. It is critical that we embrace a new nexus between food, water and energy rather than treating them in different "silos". All three need to be fully integrated, not treated separately if we are to deal with the global food security crisis. It is time to embrace a second green revolution — an "evergreen revolution" — that doubles yields but builds on sustainability principles;

b. It is time for bold global efforts, including launching a major global scientific initiative, to strengthen the interface between science and policy. We must define, through science, what scientists refer to as "planetary boundaries", "environmental thresholds" and "tipping points". Priority should be given to challenges now facing the marine environment and the "blue economy";

c Most goods and services sold today fail to bear the full environmental and social cost of production and consumption. Based on the science, we need to reach consensus, over time, on methodologies to price them properly. Costing environmental externalities could open new opportunities for green growth and green jobs;

d. Addressing social exclusion and widening social inequity, too, requires measuring them, costing them and taking responsibility for them. The next step is exploring how we can deal with these critical issues to bring about better outcomes for all;

e. Equity needs to be at the forefront. Developing countries need time, as well as financial and technological support, to transition to sustainable development. We must empower all of society - especially women, young people, the unemployed and the most vulnerable and weakest sections of society.

f. Any serious shift towards sustainable development requires gender equality. Half of humankind's collective intelligence and capacity is a resource we must nurture and develop, for the sake of multiple generations to come.

g. Many argue that if it cannot be measured, it cannot be managed. The international community should measure development beyond gross domestic product (GDP) and develop a new sustainable development index or set of indicators;

h. Financing sustainable development requires vast new sources of capital from both private and public sources. It requires both mobilizing more public funds and using global and national capital to leverage global private capital through the development of incentives.

i. Governments at all levels must move from a silo mentality to integrated thinking and policymaking. They must bring sustainable development to the forefront of their agendas and budgets and look at innovative models of international cooperation. Cities and local communities have a major role to play in advancing a real sustainable development agenda on the ground;

j. International institutions have a critical role. International governance for sustainable development must be strengthened by using existing institutions more dynamically and by considering the creation of a global sustainable development council and the adoption of sustainable development goals;

k. Governments and international organizations should increase the resources allocated to adaptation and disaster risk reduction and integrate resilience planning into their development budgets and strategies;

1. Governments, markets and people need to look beyond short-term transactional agendas and short-term political cycles. Incentives that currently favour short-termism in decision-making should be changed. Sustainable choices often have higher up-front costs than business as usual. They need to become more easily available, affordable and attractive to both poor consumers and low-income countries.

18. This Panel believes it is within the wit and will of our common humanity to choose for the future. This Panel therefore is on the side of hope. All great achievements in human history began as a vision before becoming a reality. The vision for global sustainability, producing both a resilient people and a resilient planet, is no different.

Extracted from the Report of the UN Secretary General High Level Panel on Global Sustainability http://www.un.org/wcm/content/site/climatechange/pages/gsp 